\title{
CONSTRUCTION SYSTEM FOR THE ERECTION OF PREFABRICATED BUILDINGS OUT OF FACTORY-MADE MODULES
}

\author{
Antonina Yudina*, Sergey Sychov, Anton Gaido \\ Saint Petersburg State University of Architecture and Civil Engineering \\ Vtoraja Krasnoarmeyskaya st., 4, Saint Petersburg, Russia \\ *Corresponding author: yudinaantonina2017@mail.ru
}

\begin{abstract}
Introduction: The article presents a study and justification of the concept for the erection of prefabricated buildings out of modules on a pre-arranged foundation with a comprehensive assessment of quality, accuracy, constructability and safety of building superstructure blocks. Purpose of the study: Development of rapid construction is driven by the need for affordable housing in Russian towns and cities, the need for the erection of buildings of various purposes within short time frames in regions with severe and extreme climate. Methods: Prefabricated construction is a promising industry, but it is required to perform studies on the selection of optimal organizational and technological solutions, aligning those with modern standards and requirements. Results: The authors consider a method of choosing a technique for the construction of pile foundations for multi-purpose prefabricated buildings with account for the analysis of existing loads and structural features. Determination of constructability criteria makes it possible to assess the comparative efficiency of the prefabricated-construction techniques with account for data of geotechnical surveys, conditions of a construction site, etc.
\end{abstract}

Keywords
Construction systems, prefabricated buildings, module, pile foundations, constructability criteria.

\section{Introduction}

Further development and implementation of the advantages of the construction system for the erection of prefabricated buildings out of factory-made modules is complicated due to the lack of necessary justification for the use of modular systems in complex construction conditions, a single methodology of design, transportation, assembly and disassembly of prefabricated modular buildings, as well as the lack of production facilities for module manufacturing, or their poor technical condition (Anderson and Anderson, 2007; Wang et al., 2007).

The use of modernized building complexes will make it possible to create a construction system of prefabricated buildings made out of factory-made modules with a prearranged foundation, connected utilities, roads, public services and amenities, etc.

The duration of the construction of modernized building complexes should be determined at the preparatory stage for the production and manufacturing of modules at factories using robotic conveyor belts. In this case, the labor efforts can be distributed as follows: $80-90 \%-$ manufacturing at factories and $10-20 \%$ - manufacturing at the construction site.

When modules are delivered to the construction site by means of handling machinery and vehicles, their rational storage at manufacturers' warehouses will make it possible to reduce the transportation costs by $12-16 \%$ and idle hours of crews by $8 \%$ (on average).
To determine the optimal number of vehicles when designing schedules of their operation, several assembly processes and corresponding service vehicles can be combined into unified complex logistics systems.

The use of BIM when designing and developing a construction method statement and a work method statement makes it possible to promptly account for all design changes in real time. When a design is developed, it becomes possible to refer repeatedly to the database and compare alternative options of various technologies, select an optimal solution using the extensive database of regulatory data on materials, machinery, and working procedures. There is no need for graphic representation of a design, time-consuming calculations, extensive description, or standard schemes not related to the real conditions. The possibility of visual assembly of high-tech modular systems with a detailed elaboration of embedded utilities is the main advantage of this technology.

The foundation structure is usually chosen based on traditional approaches to the design process with account for the analysis of acting loads, design features of the structure, and geotechnical conditions of the construction site.

For buildings with less than four floors, it is expedient to erect foundations as solid monolithic slabs with a thickness of $350-400 \mathrm{~mm}$, strip footings under support columns, columnar elements suitable for homogeneous soil conditions that rule out the differential settlement. 
For high-rise buildings or construction in soft watersaturated heterogeneous soils, pile foundations shall be considered with slab or strip rafts (more rarely — with stand-alone rafts).

When high-rise buildings are constructed, a combined piled-raft solution is the most reliable. In this case, during building operation, a part of the load from the piles will be transferred and redistributed to the raft slab (up to $20 \%$ ).

\section{Materials and methods}

Construction system for the erection of prefabricated buildings out of factory-made modules. It is impossible to improve construction systems for the erection of prefabricated buildings out of factory-made modules without a methodology and a set of R\&D and experimental developments using state-of-the-art technical equipment, control and measurement instrumentation, as well as software \& hardware diagnostics and online monitoring systems (Nadim and Goulding, 2010; Knaack et al., 2012).

The issue becomes even more relevant when quality, reliability and safety requirements are raised for the assembly, disassembly, transportation, and operation of prefabricated buildings of various purposes, especially in unfavorable construction conditions (Afanasyev, 1998, 2000; Kazakov, 2004; Verstov and Badjin, 2010).

Modernization of prefabricated construction means improvement and optimization of all processes, development and introduction of new equipment, materials, production methods, the need for retrofitting and upgrading production facilities through new computer technologies while reducing energy consumption (Sychev, 2015a, 2015b).

When solving tasks for the optimization of process solutions for the erection of prefabricated buildings out of factory-made modules, a game-theory model in the form of a process graph has been used that includes individual blocks and elements of the operation cycle and schemes providing an efficient prefabricated-construction technology.

Choosing foundation construction methods. Two methods are used in practical foundation engineering: installation of factory-made solid, reinforced-concrete and prismatic piles using various techniques, and installation of bored cast-in-situ piles.

Factory-made piles can be installed in three ways: by driving, by jacking, or by vibration. Besides, the following cast-in-situ techniques are widely used:

A. Bored piles with soil removal:

- a pile is installed by rotation drilling with a borehole being washed with slurry;

- a pile hole is made using a continuous flight auger;

- piles are installed using casing with soil removal by augers or special drilling tools fixed to an extension rod;

- piles are installed using reinforced-concrete shells inserted by vibration with soil removal from the internal space of the shells by a vibration clamshell bucket fixed to the rope of a hoisting machine;
- double rotation using a rotating casing pipe, inside which a flight auger operates.

B. Cast-in-situ piles without soil removal:

- a hollow casing pipe with a sacrificial shoe is screwed in. As the pipe is removed, the cavity in the soil is filled in with concrete;

- sinking of a casing pipe with a sacrificial shoe by vibration;

- driving of a casing pipe with a sacrificial shoe and its removal using a vibration generator;

- a casing pipe equipped with a displacement auger is screwed in. As the pipe is removed, the cavity is filled in with a concrete mix displacing the soil from the pile hole (the method is also called "displacement piling") (Judina et al., 2013; Verstov and Judina, 2015).

Each of the listed techniques has its advantages and disadvantages in specific geotechnical conditions. For example, the use of factory-made piles means the guaranteed quality of the pile shaft, high performance, and relatively low cost for the installation of a linear meter of a pile. The disadvantage of this technique is limitations on the dimensions and bearing capacity, and dynamic effects on the environment during pile sinking.

The advantage of cast-in-situ techniques is in the universal dimensions (length - up to $80 \mathrm{~m}$, diameter $0.2-2.0 \mathrm{~m}$ ) and possible transmission of large loads on the soil (more than 3000 tons), and the main disadvantage is that they do not guarantee pile shaft integrity, especially when works are performed in soft soils.

Therefore, it is especially important to choose expedient techniques of pile foundation construction as early as at the stage of site preparation for development and when the developer sets a design assignment with account for the requirements for the techniques depending on the location of the facility:

- when the area for development is free, construction works can be conducted without limitations on the dynamic effects in the soil;

- when works are performed in a build-up area, we should consider the distance from the existing buildings and structures to the facility under construction, i.e. socalled areas of responsibility: whether they are adjacent, at a distance of less than $20 \mathrm{~m}, 20-30 \mathrm{~m}$ or more than $30 \mathrm{~m}$.

The foundation construction method is chosen based on an analysis of the integrated quantitative specification of different methods of preparatory works, which makes it possible to assess the efficiency of their use in a single rating scale with account for different geotechnical conditions of construction sites (Gaido, 2011; Gaido et al., 2012).

\section{Results}

Construction system for the erection of prefabricated buildings out of factory-made modules

The erection of prefabricated buildings out of factorymade modules on a pre-arranged foundation with readymade infrastructure (roads, public services and amenities, utilities, etc.) makes it possible to construct buildings within short time frames in complex and extreme climatic and geological conditions. 
Utility lines are embedded in the structural modules of load-bearing walls and floor slabs, and finishing is made at the factory. The frame structures are connected by means of high-strength bolts.
A general view of a construction system for the erection of prefabricated buildings out of factory-made modules and its main structural elements are given in Figure 1.

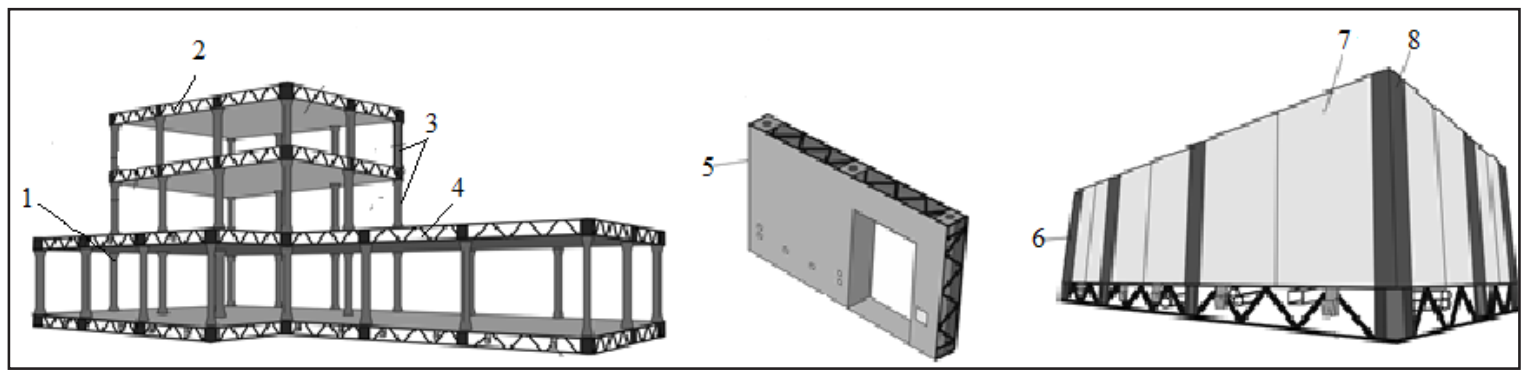

Figure 1. A construction system for the erection of prefabricated buildings out of factory-made modules 1 - a construction system including standard modules assembled; 2 - a floor slab; 3 - support columns; 4 - embedded utility lines; 5 - load-bearing walls; 6 - a general view of the construction system; 7 - enclosure panels; 8 - insulated glazing.

The tools and techniques ensuring accuracy, quality and automation of assembly methods for prefabricated buildings allow for the assembly of modules and their transportation to the construction site as well as prompt quality control. The table below presents the technical and economic indicators of assembly methods for prefabricated buildings made out of factory-made modules.

Table 1.

\begin{tabular}{|c|c|c|c|c|c|}
\hline \multirow[b]{2}{*}{ Indicators } & \multicolumn{5}{|c|}{ Module assembly methods } \\
\hline & Non-restricted & $\begin{array}{l}\text { With partial } \\
\text { confinement of } \\
\text { movement }\end{array}$ & Semi-restricted & Sem-automated & $\begin{array}{l}\text { Automated } \\
\text { assembly using } \\
\text { robots }\end{array}$ \\
\hline $\begin{array}{l}\text { element } \\
\text { fixation }\end{array}$ & w/o stoppers & with stoppers & $\begin{array}{l}\text { guide or } \\
\text { movable truss }\end{array}$ & box-unit group guide & assembly bench \\
\hline equipment & flexible ropes & $\begin{array}{l}\text { cross beams with } \\
\text { flexible connections }\end{array}$ & $\begin{array}{l}\text { cross beams with } \\
\text { rigid connections }\end{array}$ & $\begin{array}{l}\text { guide with rigid } \\
\text { clamps }\end{array}$ & robotic arm \\
\hline $\begin{array}{l}\text { accuracy of } \\
\text { assembly }\end{array}$ & up to $20 \mathrm{~mm}$ & up to $7.5 \mathrm{~mm}$ & up to $5 \mathrm{~mm}$ & up to $2 \mathrm{~mm}$ & up to $0.1 \mathrm{~mm}$ \\
\hline $\begin{array}{c}\text { labor } \\
\text { intensity, \% }\end{array}$ & 100 & 75 & 60 & 45 & 30 \\
\hline cost, \% & 100 & 85 & 70 & 50 & 40 \\
\hline duration, \% & 100 & 60 & 50 & 20 & 10 \\
\hline
\end{tabular}

\section{Choosing foundation construction methods}

The foundation construction method is selected based on an analysis of the values of constructability criteria: integrated specification of different methods of preparatory works (foundation construction), which makes it possible to assess their comparative efficiency in a single rating scale with account for different geotechnical conditions.

Constructability is evaluated by three levels of criteria: integral criteria; generalized criteria for the evaluation of pile foundation construction options (production, reliability, and quality), differential or simple criteria (technical and economic indicators).

Production criteria characterize a technique under consideration in terms of labor intensity, minimum required area dimensions, and transportation capacity of a drilling rig or a pile driver. Constructability, which determines quality and reliability, characterizes techniques in terms of negative impact on the environment (air emissions, noise emissions, soil contamination with drilled cuttings, etc.) and existing buildings and structures in the form of their deformations.

Simple criteria (technical and economic indicators) characterize techniques in terms of cost of works, material costs, and additional technological actions.

To evaluate constructability for each option, all criteria should be measured in commensurable values: integral $0 \leq J_{i} \leq 1$; generalized $-0 \leq m_{i} \leq 1$; differential $-0 \leq m_{i j} \leq 1$.

To meet the above condition, all particular values xij are transformed into dimensionless quantities using the following equations:

$$
m_{i}=\frac{x_{i j}}{x_{1}^{\max }}
$$




$$
m_{i j}=\frac{x_{i}^{\min }}{x_{i j}},
$$

Equation (1) is used when an increase in the indicator under consideration results in an increase of the generalized and integral criteria, otherwise, equation (2) should be applied.

The generalized and integral criteria are calculated using the following equations:

$$
\begin{aligned}
& m_{i}=\sum_{i=1}^{n} m_{i j} K_{i}^{\text {generalized }}, \\
& J_{i}=\sum_{i=1}^{n} m_{i} K_{i}^{\text {integral }}
\end{aligned}
$$

where $K_{i}^{\text {generalized }}, K_{i}^{\text {integral }}$ are the weight coefficients of the $i^{\text {th }}$ generalized and integral criteria, respectively, determined using the Delphi method (polling of experts in foundation engineering).

This method allows us to choose techniques for the construction of pile foundations for prefabricated buildings under various conditions of construction sites.

Let us consider the use of the above method in various situations.

Construction of a prefabricated building in soft watersaturated clayey soils on an undeveloped construction site

For such conditions, a foundation on prefabricated reinforced-concrete piles (quantity -297 , length -22 $\mathrm{m}$, cross-section $-350 \times 350 \mathrm{~mm}$ ) or cast-in-situ piles (diameter $-450 \mathrm{~mm}$ ) will be required. The design load per pile is $1200 \mathrm{kN}$.

Leaving out intermediate calculations, we obtain a ranked list of various techniques for the construction of pile foundations in descending order, which includes technique names and corresponding values of constructability criteria $\left(J_{i}\right)$ :

1. Percussion drilling of factory-made reinforcedconcrete piles $\left(J_{i}=0.75\right)$.

2. Installation of cast-in-situ piles by driving of a casing pipe and its vibratory removal $\left(J_{i}=0.71\right)$.

3. Installation of cast-in-situ piles with screwing-in of a casing pipe with a sacrificial shoe $\left(J_{i}=0.69\right)$.

4. Installation of cast-in-situ piles using the displacement method $\left(J_{i}=0.68\right)$.

5. Installation of drilled piles using flight augers $\left(J_{i}=0.60\right)$.

6. Installation of drilled piles using slurry $\left(J_{i}=0.55\right)$.

The ranking analysis shows the following:

- percussion drilling of factory-made reinforcedconcrete piles - constructability criterion $J_{i}=0.75$ (the largest value) - is the most efficient.

- installation of piles with constructability criteria $J_{i}=$ 0.60 and 0.55 is not recommended. Such works in soft soils lead to the loss of pile shaft quality (such defects as fractures and necking, voids, frame denudation, etc.). It should be noted that, in Europe, driving of prismatic piles is rarely used for civil engineering purposes.
Construction of foundations for prefabricated buildings near existing residential houses (space-limited environment)

For the implementation of the project, we will consider pile foundation (325 piles, length $-28 \mathrm{~m}$, cross-section of a factory-made pile $-400 \times 400 \mathrm{~mm}$ ) or a cast-in-situ pile foundation (diameter of a pile $-520 \mathrm{~mm}$ ). The design load per pile is $1400 \mathrm{kN}$.

As a result of constructability criteria determination for the space-limited environment, we obtain the following ranked list of techniques for the construction of pile foundations in descending order:

1. Jacking of factory-made reinforced-concrete piles $\left(J_{i}=0.80\right)$.

2. Installation of cast-in-situ piles with a screwing-in of a casing pipe with a sacrificial shoe $\left(J_{i}=0.79\right)$.

3. Installation of drilled piles using the displacement method $\left(J_{i}=0.78\right)$.

4. Installation of drilled piles using flight augers $\left(J_{i}=0.70\right)$.

5. Installation of drilled piles using slurry $\left(J_{i}=0.61\right)$.

6 . Installation of drilled piles in casing pipes using a kelly bar $\left(J_{i}=0.60\right)$.

The results obtained show that the method of jacking factory-made piles has the best constructability criterion value: $J_{i}=0.80$. However, it should be noted that this technique is efficient for design loads per pile up to 1500 (1600) kN. For loads exceeding these values, cast-in-situ pile construction should be used.

Besides, during pile jacking or when the displacement method is used near existing buildings with performance exceeding 200 linear meters of piles per shift, the soil and the existing structures may rise, which will lead to extra differential settlements. To avoid such negative consequences, calculations should provide for "protection" measures such as sheet piling, restricted performance, preliminary soil loosening with flight augers, reducing soil resistance.

\section{Conclusion}

Improvement and modernization of construction systems for prefabricated construction out of factorymade modules (as compared to new construction) increase performance per worker by $35-40 \%$, save capital investments in general construction works by 25 $30 \%$ since they do not include costs for preparatory works (excavation works, foundation construction, laying utility networks, etc.).

The method of choosing the foundation structure and techniques of its construction in case of multi-purpose prefabricated buildings, based on an analysis of advantages and disadvantages of pile foundation construction techniques and determination of constructability criteria, makes it possible to determine the efficiency of their use in prefabricated construction with account for data of geotechnical surveys, conditions on a construction site, etc.

The practical relevance of the study lies in the establishment of the scientific framework for the integrated modernization of the prefabricated-construction system. 


\section{References}

Afanasyev, A. V. (1998). Organization of the construction of prefabricated buildings and structures. In: Mobile prefabricated buildings and structures. Prospects of use in modern conditions. Saint Petersburg: Stroyizdat, pp. 226-230.

Afanasyev, A. A. (ed.) (2000). Technology of the construction of prefabricated buildings. Moscow: ASV Publishing House, 361 p. Anderson, M. and Anderson, P. (2007). Prefab prototypes: Site-specific design for offsite construction. New York: Princeton Architectural Press, $264 \mathrm{p}$.

Gaido, A. N. (2011). The purposes and tasks of investigating the technological solutions in regard of the arrangement of multi-story buildings and structures' foundations. Bulletin of Civil Engineers, 4, pp. 81-90.

Gaido, A. N., Verstov, V. V. and Ivanov, Ya. V. (2012). Technology and integrated mechanization of grooving and piling. $2^{\text {nd }}$ edition. Saint Petersburg: Lan, 288 p.

Judina, A., Gajdo, A. and Verstov, V. (2013). Comparative efficiency investigation of various types of dynamic influences on the dipped pile. World Applied Sciences Journal, 23 (6), pp. 817-822.

Kazakov, Yu. N. (ed.) (2004). Theory and practice of the use of prefabricated buildings in standard conditions and emergencies in Russia and abroad. Saint Petersburg: Humanistika, $463 \mathrm{p}$.

Knaack, U., Chung-Klatte, Sh. and Hasselbach, R. (2012). Prefabricated systems: principles of construction. Basel: Walter de Gruyter, 133 p.

Nadim, W. and Goulding, J. S. (2010). Offsite production in the UK: the way forward? A UK construction industry perspective. Construction Innovation: Information, Process. Management, 10 (2), pp. 181-202. DOI: 10.1108/14714171011037183.

Sychev, S. A. (2015a). Modeling processes of the high-speed construction of modular buildings. Montazhnye $i$ Spetsialnye Raboty $v$ Stroitelstve, 11, pp. 30-32.

Sychev, S. A. (2015b). System analysis of high-speed construction in Russia and abroad. Science Prospects, 9, pp. $126-131$.

Verstov, V. V. and Badjin, G. M. (2010). Peculiarities of designing and constructing buildings and structures in Saint-Petersburg. Bulletin of Civil Engineers, 1, pp. 96-104.

Verstov, V. and Judina, A. (2015). Improving technological processes for borehole drilling in construction using vibration impact. Applied Mechanics and Materials, Vols. 725-726, pp. 220-225. DOI: 10.4028/www.scientific.net/AMM.725-726.220.

Wang, Y., Huang, Z. and Heng, L. (2007). Cost-effectiveness assessment of insulated exterior wall of residential buildings in cold climate. International Journal of Project Management, 25 (2), pp. 143-149. DOI: 10.1016/j.ijproman.2006.09.007. 


\section{СТРОИТЕЛЬНАЯ СИСТЕМА ВОЗВЕДЕНИЯ ПОЛНОСБОРНЫХ ЗДАНИЙ ИЗ ГОТОВЫХ МОДУЛЕЙ}

Антонина Федоровна Юдина*, Сергей Анатольевич Сычев, Антон Николаевич Гайдо

Санкт-Петербургский государственный архитектурно-строительный университет

2-ая Красноармейская ул., 4, Санкт-Петербург, Россия

*E-mail: yudinaantonina2017@mail.ru

\section{Аннотация}

Введение. В статье представлено исследование и обоснование концепции возведения полносборных зданий из модулей на готовом фундаменте с комплексной оценкой качества, точности, технологичности и безопасности возведения надземных частей зданий. Цель исследования. Развитие скоростного строительства обусловлено потребностью в доступном жилье в малых и средних городах России, необходимостью возведения зданий различного назначения в короткие сроки в районах с суровыми и экстремальными условиями. Методы. Полносборное строительство является перспективным, но необходимы исследования по выбору оптимальных организационных и технологических решений, приведение их в соответствие с современными требованиями и нормами. Результаты. Рассмотрена методика выбора способов устройства свайных фундаментов многофункциональных сборных зданий с учетом анализа существующих нагрузок и конструктивных особенностей здания. Расчет критериев технологичности позволяет определить сравнительную эффективность их применения для полносборного строительства с учетом данных инженерногеологических изысканий, условий строительной площадки и т. п.

\section{Ключевые слова}

Строительные системы, полносборные здания, модуль, свайные фундаменты, критерии технологичности. 